\title{
PROGRAM PENGEMBANGAN PRODUK UNGGULAN DAERAH JAMUR TIRAM DI DESA MINDAHAN KIDUL KABUPATEN JEPARA
}

\author{
Muhammad Sagaf $^{1 *}$, Desti Setiyowati ${ }^{2}$, R. H Kusumodestoni ${ }^{3}$, Solikhul Hidayat ${ }^{4}$ \\ ${ }^{1}$ Program Studi Teknik Elektro Fakultas Sains dan Teknologi UNISNU Jepara \\ Jl. Taman Siswa (Pekeng) Tahunan Jepara \\ ${ }^{2}$ Program Studi Budidaya Perairan Fakultas Sains dan Teknologi UNISNU Jepara \\ Jl. Taman Siswa (Pekeng) Tahunan Jepara \\ ${ }^{3}$ Program Studi Teknik Informatika Fakultas Sains dan Teknologi UNISNU Jepara \\ Jl. Taman Siswa (Pekeng) Tahunan Jepara \\ ${ }^{4}$ Program Studi Manajemen Fakultas Ekonomi dan Bisnis \\ Jl. Taman Siswa (Pekeng) Tahunan Jepara \\ "Email:sagaf_mnwr@yahoo.com
}

\begin{abstract}
Abstrak
AJJ Jamur Tiram (mitra) merupakan salah satu UMKM yang membuat bibit F2, media tanam (baglog) dan membudidayakan jamur tiram. Mitra memiliki permasalahan diantaranya proses sterilisasi bibit dengan kegagalan 30\%-50\%, proses produksi baglog masih manual menggunakan tenaga manusia, pembudidayaan jamur juga masih tradisional dimana pengaturan suhu dan kelembaban rumah jamur (kumbung) dilakukan dengan menyiramkan air ke lantai dan seringnya diserang hama tikus. Pada saat hasil panen melimpah kesulitan untuk memasarkan yang mengakibatkan hasil panen membusuk dikarenakan jamur tiram segar tidak tahan disimpan lama. Selain itu mitra juga memiliki kendala dalam hal manajemen usaha, financial dan SDM. Metode yang digunakan untuk mengatasi permasalahan diatas adalah sosialisasi, workshop, pendampingan, monitoring, dan evaluasi. Hasil peningkatan manfaat dari program pengembangan produk unggulan daerah adalah (1) peningkatan kapasitas produksi bibit $700 \%$ (2) peningkatan kapasitas produksi baglog $100 \%$ (3) peningkatan kapasitas budidaya jamur tiram $230 \%$ (4) peningkatan jumlah aset $400 \%$ (5) peningkatan kemampuan manajemen $100 \%$ dan (6) peningkatan pendapatan/omset $50 \%$.
\end{abstract}

\section{Kata Kunci : Jamur Tiram, Baglog, Kumbung}

\section{PENDAHULUAN}

Index ketahanan pangan suatu negara dapat dinilai dari beberapa faktor diantaranya adalah ketersediaan pangan. Jamur tiram meskipun tidak tergolong jenis kebutuhan pangan pokok, tetapi banyak diminati oleh masyarakat karena kandungan gizinya yang tinggi. Budidaya jamur tiram banyak dilakukan didaerah yang beriklim sejuk seperti di pegunungan. Kabupaten Jepara meskipun berada dipesisir pantai tetapi juga memiliki daerah pegunungan yang beriklim sejuk dikarenakan ketinggian permukaan tanah dari permukaan air laut wilayah Kabupaten Jepara terletak mulai dari $0 \mathrm{~m}-1.301 \mathrm{~m}$. Ketersediaan bahan baku yang melimpah untuk media tanam jamur berupa serbuk kayu (gergajen) juga ikut mendukung budidaya jamur tiram di daerah Jepara, sebab Jepara merupakan sentra usaha mebel yang banyak menghasilkan limbah serbuk gergajen (Badan Pusat Statistik, 2019).

AJJ Jamur Tiram (mitra) merupakan salah satu UMKM pembudidaya jamur tiram yang ada di kabupaten Jepara yang berdiri sejak tahun 2014 dan pemiliknya adalah Bapak Ahmad Jamal. Lokasi mitra terletak di desa Mindahan Kidul kecamatan Batealit kabupaten Jepara. Usaha yang dikembangkan oleh mitra adalah produksi bibit F2, baglog untuk media tanam jamur dan budidaya jamur tiram segar di dalam kumbung (rumah untuk budidaya jamur tiram).

Proses produksi bibit $\mathrm{F} 2$ dilakukan dengan melakukan penurunan dari bibit F0 dan dilakukan proses sterilisasi menggunakan panci presto dengan kapasitas 5 botol. Proses tersebut hanya mendapatkan $50 \%-70 \%$ bibit F2 yang siap untuk digunakan sebagai bibit pada media tanam jamur (baglog). Pada proses produksi baglog, pencampuran bahan-bahan yang digunakan hanya berdasarkan perkiraan menggunakan mangkuk dan ember. Selanjutnya campuran diaduk agar merata menggunakan cangkul oleh karyawan. Kandungan air/kelembaban pada campuran hanya dikira-kira menggunakan telapak tangan. Hasil campuran yang sudah jadi dimasukkan kedalam plastik secara manual menggunakan tenaga manusia dan dipadatkan dengan cara dipukul-pukulkan 
ke tanah. Media baglog yang sudah siap disterilkan menggunakan alat sterilisasi dari drum bekas menggunakan kompor gas. Lama waktu dan suhu proses sterilisasi hanya menggunakan perkiraan saja. Baglog yang sudah jadi di jual ke konsumen petani budidaya jamur dan sebagian di budidayakan sendiri di kumbung jamur mitra. Hasil budidaya berupa jamur tiram segar dijual di warung dan pasar sekitar mitra. Selain itu, mitra juga menampung jamur segar hasil budidaya petani jamur yang lain.

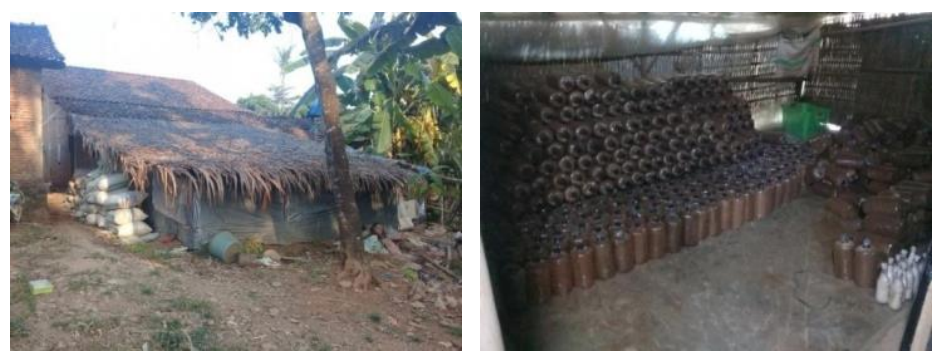

Gambar 1. Lokasi mitra (kiri) dan ruang produksi bibit dan baglog (kanan)

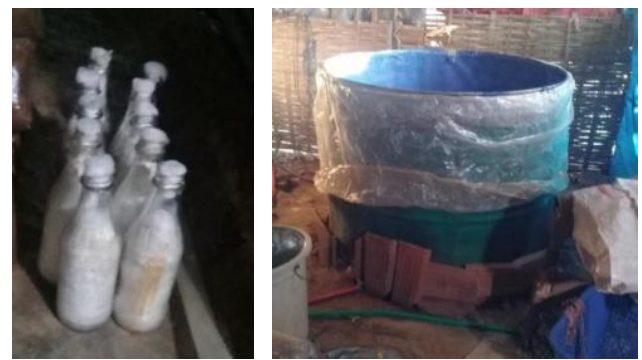

Gambar 2. Bibit F2 (kiri) dan Alat sterilisasi baglog (kanan)
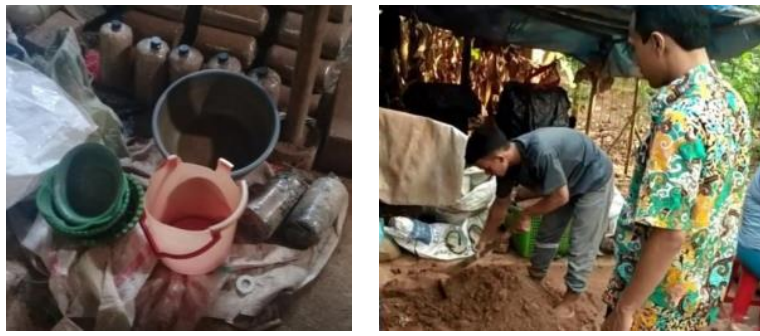

Gambar 3. Alat takaran campuran (kiri), pengadukan bahan campuran baglog (kanan)
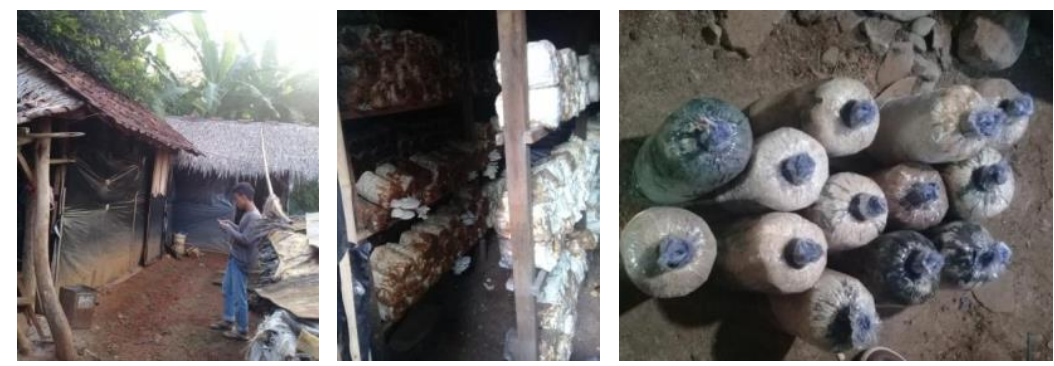

Gambar 4. Kumbung tempat budidaya jamur (kiri), baglog yang tidak produktif (tengah) dan baglog yang rusak/gagal (kanan)

Berdasarkan hasil pengamatan dilapangan dapat diketahui permasalahan-permasalahan yang ada pada mitra AJJ Jamur Tiram. Hal ini yang menjadikan hasil produksi baglog dan jamur tiram masih belum mampu dijadikan sebagai salah satu penghasilan utama dari masyarakat Desa Mindahan Kidul. Permasalahan yang dihadapi diuraikan pada tabel 1. 
Tabel 1. Permasalahan Mitra

\begin{tabular}{|c|c|}
\hline Persoalan & $\begin{array}{c}\text { Mitra } \\
\text { (AJJ Jamur Tiram) } \\
\end{array}$ \\
\hline Bahan Baku & $\begin{array}{l}\text { - Bahan baku serbuk gergajen kayu sengon hanya mengandalkan dari } 3 \\
\text { tempat penggergajian kayu disekitar desa mitra. Pada saat permintaan } \\
\text { banyak terkadang suplai serbuk gergajen kurang. } \\
\text { - Baglog untuk budidaya hanya mengandalkan hasil produksi sendiri, } \\
\text { sehingga sering kekurangan terutama pada saat permintaan baglog dari } \\
\text { pembudidaya lain melonjak dikarenakan kapasitas produksi baglog hanya } \\
250 \text { baglog/hari. }\end{array}$ \\
\hline Produksi & $\begin{array}{l}\text { - Alat produksi bibit F2 masih menggunakan panci presto kapasitas } 1,5 \text { liter, } \\
\text { hal ini selain kapasitasnya rendah juga tingkat kegagalan hasilnya mencapai } \\
\text { 30-50\%. } \\
\text { - Alat penakar jumlah campuran bahan untuk baglog hanya menggunakan } \\
\text { mangkuk dan ember, sehingga jumlah takaran tidak stabil. Selain itu } \\
\text { kelembaban campuran hanya dikira-kira menggunakan sentuhan tangan } \\
\text { karena belum mempunyai alat pengukur kelembaban (Gambar 3. kiri). } \\
\text { - Pengadukan bahan campuran baglog masih diaduk manual menggunakan } \\
\text { cangkul, belum menggunakan alat pengaduk/mixer. Sehingga hasil adukan } \\
\text { kurang merata dan memerlukan waktu yang lama (Gambar 3. kanan). } \\
\text { - Proses pengisian dan pemadatan baglog masih manual menggunakan tenaga } \\
\text { manusia menyebabkan hasil kurang maksimal dan memerlukan waktu yang } \\
\text { lama. Sehingga memerlukan inovasi teknologi. } \\
\text { - Kapasitas alat sterilisasi baglog hanya 250 baglog/hari, pada saat } \\
\text { permintaan baglog melonjak tidak dapat terpenuhi, sehingga perlu } \\
\text { ditingkatkan kapasitasnya. (Gambar } 2 \text {. kanan). } \\
\text { - Kondisi kumbung yang jauh dari tempat produksi selain menyulitkan } \\
\text { pengontrolan juga sering diserang hama tikus menyebabkan seringnya } \\
\text { gagal panen (Gambar 4). } \\
\text { - Belum memiliki alat produksi untuk produk olahan jamur. }\end{array}$ \\
\hline Proses & $\begin{array}{l}\text { - Proses sterilisasi baglog masih manual tanpa pengontrolan dan monitoring } \\
\text { suhu dan lamanya waktu proses. Sehingga harus sering dikontrol agar } \\
\text { jangan sampai kehabisan gas. } \\
\text { - Proses pengontrolan suhu dan kelembaban kumbung masih manual } \\
\text { menggunakan penyiraman oleh manusia sehingga suhu dan kelembaban } \\
\text { tidak terjaga dengan baik. } \\
\text { - Layout belum tertata dengan rapi (Gambar 1). }\end{array}$ \\
\hline Produk/Desain & $\begin{array}{l}\text { - Produk yang dihasilkan masih berupa bibit jamur F2 (Gambar 2. kiri), } \\
\text { baglog dan jamur tiram segar. Sehingga pada saat hasil panen jamur tiram } \\
\text { melimpah kesulitan untuk memasarkan dikarenakan sifat jamur yang tidak } \\
\text { bisa disimpan lama. Sehingga perlu dilakukan inovasi produk olahan jamur } \\
\text { tiram. } \\
\text { - Desain kemasan masih sederhana dan belum mempunyai label. }\end{array}$ \\
\hline Manajemen & $\begin{array}{l}\text { - Manajemen masih sederhana dan kekeluargaan. Belum mempunyai } \\
\text { manajemen yang standart diantaranya: (production, planning, accounting, } \\
\text { bookkeeping, auditing dan Inventory) }\end{array}$ \\
\hline Pemasaran & $\begin{array}{l}\text { - Pemasaran masih tradisional melalui mulut ke mulut, warung dan pasar } \\
\text { sekitar mitra, dan menggunakan media sosial facebook dan instagram. } \\
\text { - Belum mempunyai website dan online shop. }\end{array}$ \\
\hline SDM & - Rata-rata lulusan SD, SMP, SMA dan ketrampilannya terbatas. \\
\hline Sarana & $\begin{array}{l}\text { - Sarana ruang produksi terbatas dan perlu peningkatan untuk menunjang } \\
\text { produktivitas serta perlu penataan layout untuk memperlancar proses } \\
\text { produksi. } \\
\text { - Sarana yang diperlukan yaitu ruang pembibitan/inokulasi yang tertutup, alat }\end{array}$ \\
\hline
\end{tabular}




\begin{tabular}{|l|l|}
\hline & $\begin{array}{l}\text { sterilisasi bibit, alat sterilisasi baglog berkapasitas lebih besar dengan } \\
\text { kontrol suhu dan waktu otomatis, alat pengaduk/mixer bahan campuran } \\
\text { baglog, alat pengisi dan pemadat baglog, timbangan, alat kontrol }\end{array}$ \\
& $\begin{array}{l}\text { kelembaban, alat control suhu dan kelembaban kumbung otomatis, alat } \\
\text { pembuat produk olahan jamur tiram antara lain: kompor, penggorengan, } \\
\text { pengering/spinner dan alat pres kemasan vakum. }\end{array}$ \\
\hline Finansial & - Sumber modal dari pemilik, sehingga perluasan usaha menjadi terbatas \\
\hline
\end{tabular}

\section{METODE}

Pelaksanaan kegiatan Program Pengembangan Produk Unggulan Daerah dengan tujuan meningkatkan kualitas dan kapasitas, untuk meningkatkan omset mitra dan melestarikan budaya lokal menggunakan metode sebagai berikut :

1. Sosialisasi Kegiatan Pengabdian pada Mitra.

Sosialisasi ini bertujuan untuk memberikan pemahaman mengenai kegiatan Program Pengembangan Produk Unggulan Daerah (PPPUD) yang akan dilaksanakan, sehingga diharapkan mitra dapat berpartisipasi aktif dalam kegiatan.

2. Pelatihan Pembuatan Bibit dan Baglog

Kegiatan ini dimaksudkan untuk meningkatkan pengetahuan dan ketrampilan dari mitra agar dapat menghasilkan bibit dan baglog yang lebih baik dan tingkat kegagalan yang minimal.

3. Pelatihan E-Commerce

Kegiatan ini dilakukan untuk meningkatkan pengetahuan dan ketrampilan mitra dalam menggunakan internet sebagai media promosi produknya dan melakukan transaksi secara online.

4. Pelatihan Sistem Manajemen

Kegiatan ini dilakukan untuk meningkatkan pengetahuan dan kemampuan mitra dalam mengelola manajemen usahanya.

5. Pendampingan Penggunaan Alat-alat kepada Mitra

Pendampingan penggunaan alat-alat ini dilaksanakan agar mitra dapat memahami cara kerja dan pengoperasian dari alat-alat yang diberikan yaitu alat sterilisasi bibit (autoclave), alat pengaduk/mixer, alat press filling baglog, dan alat sterilisasi baglog dengan kontrol suhu dan waktu ini. Hal ini penting karena mitra belum pernah menggunakan alat-alat selama ini, dan juga untuk mencegah terjadinya kesalahan dan kerusakan alat-alat tersebut.

6. Studi Banding ke Pembudidaya yang lebih besar

Studi banding dilakukan untuk menambah pengetahuan dari pembudidaya yang lebih besar.

7. Renovasi ruang produksi dan relokasi kumbung

Hal ini dilakukan untuk memperbaiki layout produksi agar proses produksi berjalan lebih baik.

8. Peningkatan kapasitas produksi bibit, baglog dan budidaya jamur tiram

Metode ini dilakukan dengan memberikan bantuan bahan-bahan produksi bibit, baglog dan budidaya jamur tiram.

Berdasarkan analisis situasi, permasalahan dan metode yang sudah dijelaskan sebelumnya, maka solusi untuk menyelesaikan permasalahan dapat diuraikan pada tabel 2.

Tabel 2. Solusi Permasalahan Mitra

\begin{tabular}{|l|l|l|}
\hline \multicolumn{1}{|c|}{$\begin{array}{c}\text { Aspek } \\
\text { Bisnis }\end{array}$} & \multicolumn{1}{|c|}{$\begin{array}{c}\text { Permasalahan yang } \\
\text { akan diselesaikan }\end{array}$} & \multicolumn{1}{c|}{ Solusi yang Ditawarkan } \\
\hline $\begin{array}{l}\text { Bahan } \\
\text { Baku }\end{array}$ & $\begin{array}{l}\text { ・ Kekurangan bahan baku serbuk } \\
\text { gergajen kayu sengon }\end{array}$ & $\begin{array}{l}\text { ・ Menambah supplier serbuk gergajen } \\
\text { dari sekitar desa mitra }\end{array}$ \\
\hline Produksi & $\begin{array}{l}\text { - Produksi bibit dengan kegagalan } \\
\text { hasil mencapai 30-50\% }\end{array}$ & $\begin{array}{l}\text { - Pembuatan alat sterilisasi bibit dengan } \\
\text { kapasitas lebih besar dan suhu } \\
\text { sterilisasi lebih tinggi }\end{array}$ \\
\hline
\end{tabular}




\begin{tabular}{|c|c|c|}
\hline & $\begin{array}{l}\text { belum terkontrol dengan baik dan } \\
\text { banyak menggunakan tenaga } \\
\text { manual sehingga kapasitas } \\
\text { produksinya hanya } 250 \text { baglog/hari } \\
\text { - Belum adanya pengontrolan suhu } \\
\text { dan kelembaban kumbung dan } \\
\text { pencegahan diserang hama tikus } \\
\text { - Belum ada inovasi produksi olahan } \\
\text { jamur tiram }\end{array}$ & $\begin{array}{l}\text { - Pembuatan alat sterilisasi baglog } \\
\text { dengan kapasitas lebih besar } \\
\text { dilengkapi dengan control suhu dan } \\
\text { waktu otomatis } \\
\text { - Pembuatan alat pengaduk/mixer } \\
\text { - Pembuatan alat pengisi dan pemadat } \\
\text { baglog } \\
\text { - Pengadaan timbangan dan alat } \\
\text { pengukur kelembaban campuran } \\
\text { baglog }\end{array}$ \\
\hline Proses & $\begin{array}{l}\text { - Perbaikan lay out } \\
\text { - Proses pengontrolan suhu dan waktu } \\
\text { sterilisasi } \\
\text { - Proses pengontrolan suhu dan } \\
\text { kelembaban kumbung }\end{array}$ & $\begin{array}{l}\text { - Memperbaiki lay out } \\
\text { Melengkapi alat sterilisasi baglog } \\
\text { dengan kontrol suhu dan waktu } \\
\text { otomatis }\end{array}$ \\
\hline $\begin{array}{l}\text { Produk/De } \\
\text { sain }\end{array}$ & $\begin{array}{l}\text { - Produk hanya berupa bibit, baglog } \\
\text { dan jamur tiram segar. Belum ada } \\
\text { produk olahan jamur tiram } \\
\text { - Desain kemasan masih sederhana } \\
\text { dan belum memiliki label kemasan }\end{array}$ & $\begin{array}{l}\text { - Membuat label dan desain kemasan } \\
\text { bibit dan baglog yang menarik }\end{array}$ \\
\hline $\begin{array}{l}\text { Manajeme } \\
\mathrm{n}\end{array}$ & $\begin{array}{l}\text { - Pembenahan manajemen dan } \\
\text { pembukuan secara profesional }\end{array}$ & $\begin{array}{l}\text { - Pendampingan pembuatan laporan } \\
\text { keuangan secara berkala dalam proses } \\
\text { penyusunan pembukuan }\end{array}$ \\
\hline Pemasaran & $\begin{array}{l}\text { - Pengembangan manajemen } \\
\text { pemasaran melalui media promosi } \\
\text { secara online atau melalui pameran } \\
\text { (belum ada Website) } \\
\text { - Menjalin kerjasama untuk } \\
\text { memperluas pemasaran } \\
\end{array}$ & $\begin{array}{l}\text { - Peningkatan pemasaran melalui } e \text { - } \\
\text { commerce } \\
\text { - Mengikuti pameran yang diadakan di } \\
\text { Jepara }\end{array}$ \\
\hline SDM & $\begin{array}{l}\text { - Pendampingan dan pelatihan untuk } \\
\text { meningkatkan keterampilan SDM }\end{array}$ & $\begin{array}{l}\text { - Pelatihan proses pembuatan bibit } \\
\text { - Pelatihan pembuatan baglog } \\
\text { - Pelatihan } \text { e-commerce pemasaran } \\
\text { online }\end{array}$ \\
\hline Sarana & $\begin{array}{l}\text { - Sarana yang memadai dan proses } \\
\text { produksi berjalan lancar }\end{array}$ & $\begin{array}{l}\text { - Pembenahan layout produksi baglog } \\
\text { - Pembuatan alat sterilisasi bibit dan alat } \\
\text { bantu proses pembuatan baglog }\end{array}$ \\
\hline Finansial & $\begin{array}{l}\text { - Pendampingan akses modal dan } \\
\text { pelatihan pembukuan }\end{array}$ & $\begin{array}{l}\text { - Akses ke lembaga yang memiliki } \\
\text { pinjaman lunak }\end{array}$ \\
\hline
\end{tabular}

\section{HASIL DAN PEMBAHASAN}

Kegiatan program pengembangan produk unggulan daerah dimulai dengan survey pendahuluan untuk melihat kondisi terakhir mitra untuk menyusun dan menyesuaikan program yang telah direncanakan sebelumnya. Dilanjutkan dengan beberapa kegiatan antara lain:

1. Sosialisasi kegiatan pengabdian pada mitra untuk memberikan pengetahuan mengenai maksud dan tujuan kegiatan yang akan dilaksanakan, diharapkan dengan adanya kegiatan ini mitra dapat mengikuti dan berpartisipasi secara aktif. 


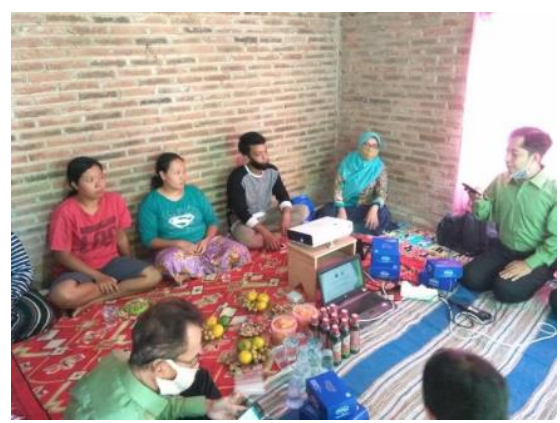

\section{Gambar 5. Sosialisasi kegiatan Program Pengembangan Produk Unggulan Daerah}

\section{Pelatihan-pelatihan}

Kegiatan pelatihan yang diadakan antara lain pelatihan E-Commerce, pelatihan sistem manajemen, dan pelatihan pembuatan bibit dan baglog. Dari kegiatan pelatihan e-commerce diharapkan dapat meningkatkan omset penjualan produk jamur, apalagi disaaat pandemi covid-19 ini kegiatan-kegiatan yang sifatnya berhubungan langsung dihindari. Sehingga sebagian besar masyarakat banyak beralih melakukan transaksi secara online. Narasumber pelatihan ini Muhamad Husein, S.Kom. dan R.H Kusumodetoni, S.Kom, M.Kom merupakan praktisi dan akademisi yang sudah berpengalaman di bidang ini. Selain itu setelah mengikuti pelatihan sistem manajemen diharapkan mitra dapat mengelola manajemen usaha, keuangan maupun manajemen sumber daya manusianya dengan lebih baik, sehingga dapat mengembangkan usahanya dan meningkatkan omsetnya. Narasumber dari kegiatan adalah bapak Sarwido, SE, MM dan Solikhul Hidayat, SE, M.Si yang merupakan praktisi dan akademisi yang sudah berpengalaman di bidang manajemen. Pelatihan pembuatan bibit dan baglog dilakukan dengan narasumber Ibu Desti Setyowati, S.Pi., M.Si. yang merupakan praktisi budidaya jamur dan akademisi yang sudah berpengalaman.
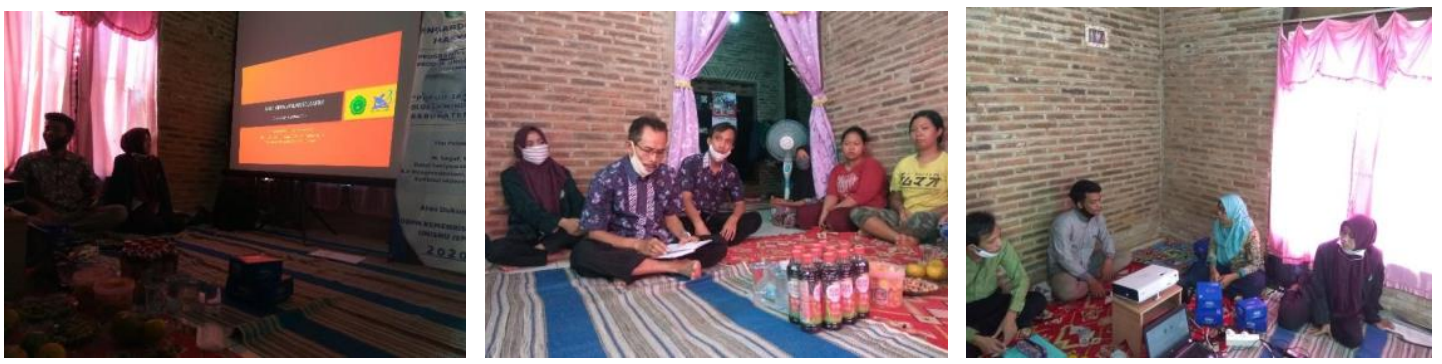

Gambar 6. Pelatihan e-commerce, sistem manajemen dan pembuatan bibit dan baglog

3. Pendampingan Penggunaan Alat-alat produksi

Pendampingan penggunaan alat-alat produksi dilakukan bersamaan dengan penyerahan alat kepada mitra. Alat-alat produksi yang diserahkan antara lain autoclave, mixer, press filling dan alat sterilisasi baglog otomatis. Pendampingan penggunaan alat penting dilakukan karena mitra selama ini belum pernah menggunakan alat-alat bantu produksi.
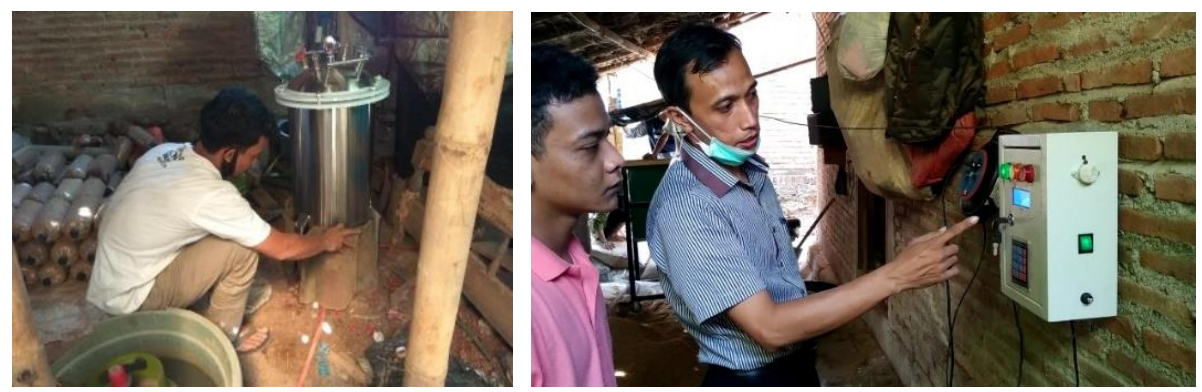

Gambar 7. Pendampingan penggunaan alat autoclave, dan alat sterilisasi baglog otomatis 

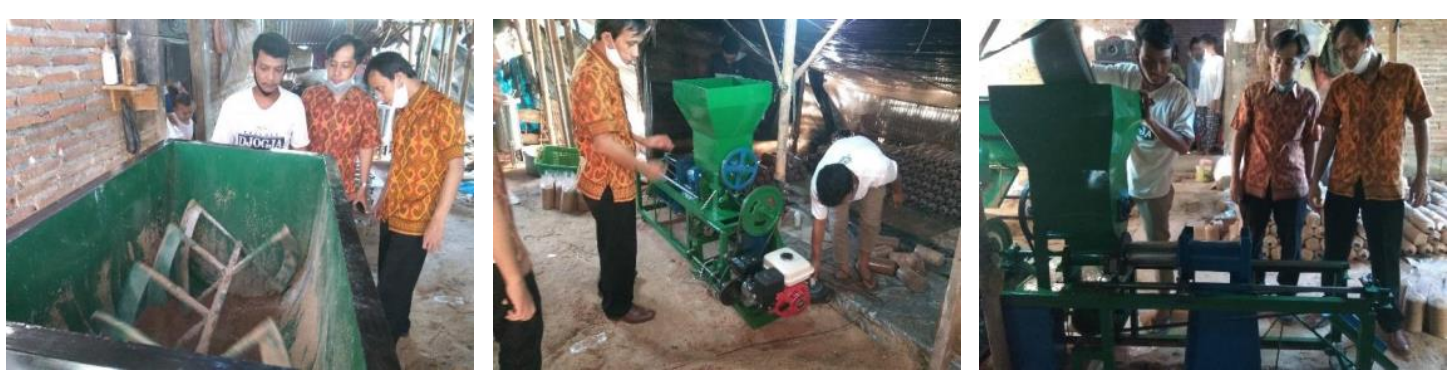

Gambar 8. Pendampingan penggunaan alat pengaduk/mixer, alat pengisi dan pemadat baglog

4. Peningkatan kapasitas produksi bibit, baglog dan budidaya jamur tiram

Peningkatan kapasitas produksi bibit, baglog dan budidaya jamur tiram dilakukan selama program pengabdian berlangsung. Hal ini dilakukan selain memberikan pelatihan, bantuan alat-alat juga pemberian bantuan bahan-bahan pembuatan bibit, baglog dan budidaya jamur tiram serta renovasi ruang produksi dan relokasi kumbung. Sehingga dapat meningkatkan hasil panen jamur tiram dan menambah omset penjualan. Peningkatan kapasitas budidaya dilakukan secara bertahap dikarenakan kondisi tempat produksi yang terbatas dengan mengatur pembelian bahan-bahan pembuatan baglog secara bertahap pula. Perbaikan dan pemindahan ini selain bertujuan agar lokasi kumbung lebih dekat dengan tempat produksi baglog dan akses jalan utama, juga bertujuan untuk menambah kapasitas kumbung agar lebih banyak. Sehingga dapat meningkatkan hasil panen jamur tiram dan menambah omset penjualan.
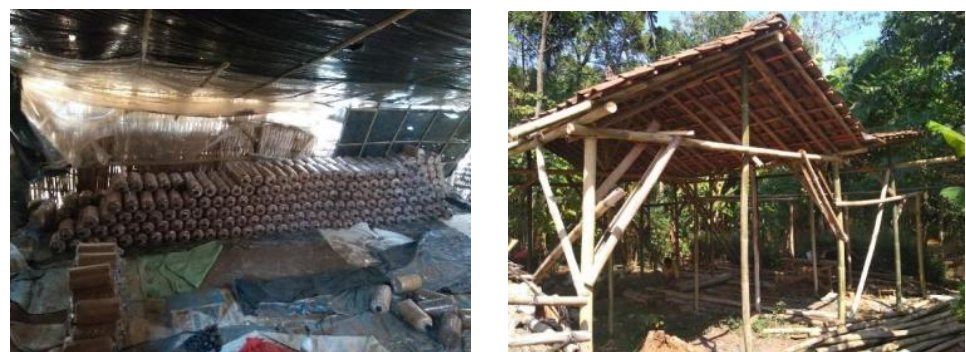

Gambar 9. Peningkatan kapasitas produksi dan renovasi kumbung

5. Kegiatan Pendukung

Kegiatan lain yang mendukung program ini antara lain studi banding 0 ke sesama pembudidaya jamur tiram di Jepara. Lokasi studi banding berada di desa Guyangan kecamatan Bangsri dengan kapasitas budidaya jamur tiram sebanyak 80.000 baglog. Bapak Ahmad Fauzi selaku pemilik UMKM Melati Jamur tiram banyak memberi masukan untuk pengembangan usaha budidaya jamur tiram mitra AJJ Jamur Tiram. Selain itu juga dilakukan seremonial penyerahan alat-alat teknologi tepat guna untuk menyerahkan alat-alat secara resmi kepada mitra.
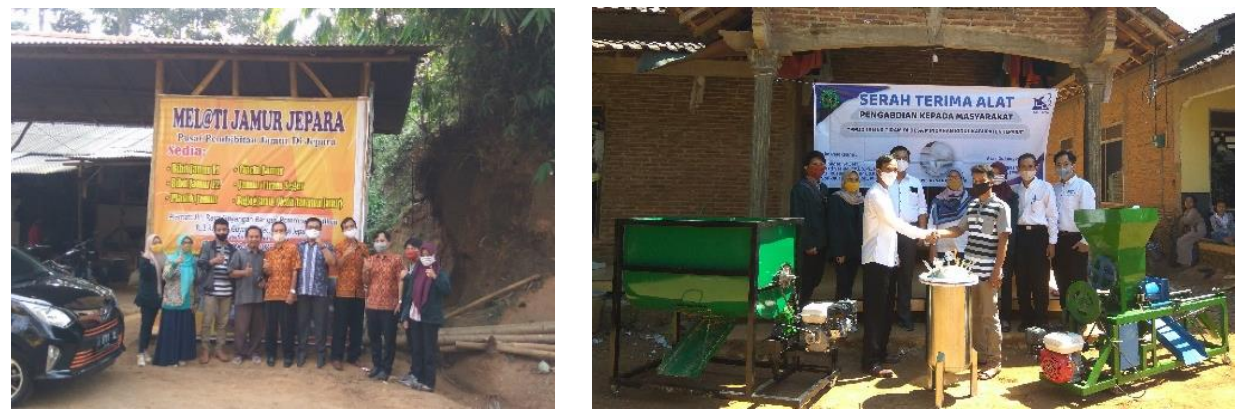

Gambar 10. Studi banding dan seremonial penyerahan alat

Kegiatan-kegiatan tersebut dilakukan untuk meningkatkan pengetahuan, ketrampilan, produksi dan omset mitra. Kegiatan pelatihan e-commerce dilakukan untuk memperluas pasar dan meningkatkan penjualan melalui berbagai media sosial. Hal ini cukup efektif dan dapat 
mengantisipasi kondisi pandemi covid karena transaksi dilakukan secara online, sehingga mengurangi interaksi fisik secara langsung. Untuk meningkatkan kemampuan manajemen dan administrasi dilakukan pelatihan sistem manajemen, dimana mitra dapat meningkatkan kemampuan untuk mengelola manajemen usaha, keuangan maupun manajemen sumber daya manusianya dengan lebih baik. Kegiatan pelatihan yang lain yaitu pelatihan pembuatan bibit dan baglog dilakukan untuk membekali pengetahuan dan ketrampilan mitra dalam proses produksi bibit dan baglog yang selama ini hanya dengan cara otodidak dan memiliki tinggat kegagalan yang tinggi. Sehingga mitra dapat memproduksi sesuai dengan ilmu dan petunjuk teknis yang sesuai (Susilowati, 2010).

Kegiatan pendampingan penggunaan alat autoclave (Susilowati, 2010) untuk sterilisasi bibit dilakukan agar mitra yang selama ini hanya menggunakan panci presto berkapasitas 5 botol dapat meningkat menjadi 40 botol dalam sekali proses produksi. Penggunaan alat mixer digunakan untuk meningkatkan kapasitas pengadukan bahan-bahan yang sebelumnya menggunakan pengadukan manual dengan cangkul, sehingga dapat mempercepat waktu pengadukan dan homogenitas campuran. Sedangkan penggunaan alat press filling untuk menggantikan proses pengisian dan pemadatan manual dengan tenaga manusia, sehingga dapat meningkatkan kapasitas produksi dari 250 baglog/hari menjadi 500 baglog/hari dan tingkat kepadatan baglog. Selain itu penggunaan alat sterilisasi baglog berkapasitas 500 baglog dengan kontrol otomatis menggunakan kontroller arduino Uno dapat menghemat penggunaan bahan bakar dan memudahkan dalam memonitor proses menggunakan SMS Gateway (Putranto, 2012).

Peningkatan produksi juga dilakukan dengan melakukan renovasi ruang produksi, relokasi dan peningkatan kapasitas kumbung jamur sehingga dapat meningkatkan kapasitas budidaya dari 3000 baglog menjadi 10000 baglog.

Hasil yang didapatkan dari program pengembangan produk unggulan daerah pada mitra dapat dilihat pada tabel 3 .

Tabel 3. Peningkatan manfaat yang diperoleh

\begin{tabular}{lccc}
\hline \multicolumn{1}{c}{ Uraian } & Sebelum Program & Setelah Program & Peningkatan \\
\hline Kapasitas produksi bibit & 5 & 40 & $700 \%$ \\
& botol/proses & botol/proses & \\
Kapasitas produksi & 250 & 500 & $100 \%$ \\
baglog & baglog/hari & baglog/hari & \\
Kapasitas budidaya & 3.000 & 10.000 & $230 \%$ \\
jamur tiram & baglog & baglog & $400 \%$ \\
Jumlah aset & 1 alat & 5 alat & \\
Kemampuan manajemen & Belum & Mampu & \\
& mampu & menggunakan & $100 \%$ \\
buku arus kas & \\
Pendapatan/omset & 20 juta/bulan & 30 juta/bulan & $50 \%$ \\
\hline
\end{tabular}

Dari berbagai kegiatan yang telah dilakukan dapat dilihat peningkatan manfaat yang diperoleh seperti terlihat pada tabel 3. Hal ini menunjukkan bahwa usaha jamur tiram cukup layak (Umniyatie, 2013) untuk dilakukan dan mempunyai peluang yang cukup bagus sebagai usaha yang menguntungkan (Shintia, 2017).

\section{KESIMPULAN}

Melalui kegiatan ini telah dihasilkan dan digunakan alat bantu proses produksi jamur tiram dari mulai alat bantu sterilisasi bibit (autoclave), alat pengaduk/mixer baglog, alat pengisi dan pemadat baglog, alat sterilisasi baglog, alat pengukur kelembaban campuran baglog, dan timbangan digital. Mitra dalam kegiatan ini dapat mengaplikasikan teknologi alat-alat bantu proses produksi bibit dan baglog jamur tiram dengan baik yang berguna untuk meningkatkan kuantitas dan kualitas dari produksi bibit dan baglog jamur tiram. Mitra dapat mengembangkan kapasitas usaha budidaya 
jamur tiramnya lebih baik dengan telah dilakukannya renovasi tempat produksi dan relokasi kumbung budidaya jamur tiram.

Terimakasih disampaikan kepada LPPM Universitas Islam Nahdlatul Ulama Jepara dan DRPM RISTEK - BRIN atas terselenggaranya program pengabdian kepada masyarakat.

\section{DAFTAR PUSTAKA}

Badan Pusat Statistik, (2019), Kabupaten Jepara Dalam Angka 2019, Badan Pusat Stastistik Kabupaten Jepara

Susilawati, \& Raharjo, B. (2010). Petunjuk Teknis: Budidaya Jamur Tiram (Pleourotus ostreatus var florida) yang ramah lingkungan. BPTP sumatera Selatan.

Putranto, M. A., \& Yamin, M. (2012). Pengendalian Suhu Ruang pada Budidaya Jamur Tiram dengan Karung Goni Basah. JTEP Jurnal Keteknikan Pertanian, 26(2), 137-142.

Umniyatie, S., Astuti, Pramiadi, D., \& Henuhili, V. (2013). Budidaya Jamur Tiram (Pleuretus.sp) Sebagai Alternatif Usaha Bagi Masyarakat Korban Erupsi Merapi Di Dusun Pandan, Wukirsari, Cangkiran, Sleman DIY. Inotek, 17(2), 162-175.

Shintia, R. D., \& Amalia. (2017). Analisis Usahatani Jamur Tiram Putuh (Pleurotus ostreatus) Di Kelurahan Simpang Baru Kecamatan Tampan Kota Pekanbaru, Jurnal Ilmiah Pertanian 13(2), 38-49. 